\title{
Palydovinės informacijos apie sniego dangą trūkių užpildymo metodų vertinimas
}

Silvija Pipiraitè-Januškienè,

Justinas Kilpys,

Egidijus Rimkus

Vilniaus universitetas,

M. K. Čiurlionio g. 21, 03101 Vilnius

El.paštas: silvija.pipiraite@gf.vu.lt; justinas.kilpys@gf.vu.lt; egidijus.rimkus@gf.vu.lt
Pipiraitė-Januškienė S., Kilpys J., Rimkus E. Palydovinės informacijos apie sniego dangą trūkių užpildymo metodų vertinimas. Geologija. Geografija. 2018. T. 4(3). ISSN 2351-7549.

Straipsnyje vertinami palydovinès informacijos apie teritorijos padengtumą sniegu trūkių užpildymo metodai. Buvo naudojami dviejų NASA palydovų Terra ir Aqua bei Lietuvos meteorologijos stočių tinklui priklausančiu stočiu sniego dangos duomenys 2013-2016 m. spalio-balandžio mėnesiais. Naudojant du skirtingus būdus (pirmyn ir atgal) buvo užpildyti palydovinių sniego dangos duomenų sekų trūkiai, atsirandantys dèl ištisinio debesuotumo. Gauti dydžiai palyginti su Lietuvos meteorologijos stotyse nustatytu dienų su sniego danga skaičiumi. Analizuojamu 2013-2016 m. laikotarpiu šaltojo sezono mènesiais palydovinių duomenų trūkiai sudarè $60 \%$ nuo bendro dienų skaičiaus. 2013-2016 m. žiemomis vidutinis dienų su sniego danga skaičius Lietuvos meteorologijos stotyse buvo 47. Remiantis Terra palydovo duomenis, šis dydis buvo 44 dienos, o pagal Aqua perduotą informaciją - 55 dienos. Kiek didesnis dienų su sniego danga skaičius nustatytas trūkius užpildžius pirmyn metodu, tačiau skirtumas yra nedidelis ir abiejų palydovų duomenys neviršija vienos dienos. Vidutiniškai sezoninis dienų su sniego danga skaičius, nustatytas remiantis palydovų duomenimis, nuo išmatuoto atskirose meteorologijos stotyse skiriasi 9 dienomis pagal Terra ir 13 dienų pagal Aqua palydovo duomenis. Dažni atodrèkiai, sniego dangos fragmentacija ir didelis debesuotumas lèmé nemažus skirtumus tarp palydovinès bei meteorologijos stočių informacijos.

Raktažodžiai: sniegas, dienų su sniego danga skaičius, Terra, Aqua, MODIS, debesuotumas, duomenų trūkiai

\section{IVADAS}

Reguliarūs antžeminiai sniego dangos stebèjimai pradeti XIX a. viduryje, o Lietuvoje tokie matavimai vykdomi nuo 1891 metų. Sniego dangos storis, vandens atsargos sniege bei teritorijos padengimas sniegu yra svarbiausi sniego dangos rodikliai, matuojami antžeminèse meteorologijos stotyse. Iš išmatuotų dydžių yra skaičiuojamos kli- matinès charakteristikos (dienų su sniego danga skaičius, maksimalus sniego storis, sniego dangos susiformavimo bei nutirpimo datos ir kt.), kuriu ilgą laikotarpi apimančios sekos suteikia daug naudingos informacijos apie vietovés klimata ir jo kaitą (Beniston, 1997; Laternser, Schneebeli, 2003; Scherrer ir kt., 2004; Scherrer, Appenzeller, 2006; Hantel, Hidrtl-Wielke, 2007; Marty, 2008; Marty, Meister, 2012). 
Pastaraisiais dešimtmečiais sniego dangos rodikliams vertinti vis plačiau naudojama palydovine informacija. Lyginant su antžeminiais matavimais, kurių tinklas - daugelyje pasaulio vietu palyginti retas (ypač tose srityse, kur sniego danga išsilaiko didžiąją metų dalị), palydovai suteikia išsamią erdvinę informaciją apie Žemès paklotinio paviršiaus būklę (Foppa, Seiz, 2012). Tačiau palydovų teikiamoje informacijoje yra nemažai trūkių. Viena svarbiausių trūkių priežasčių atliekant matavimus regimojo bei artimojo infraraudonojo spektro bangų diapazone yra debesys, kurie užstoja žemès paviršių.

Tyrẻjai, norẻdami išvengti netikslumų ir spragų, atsirandančių dèl debesų dangos, kuria įvairius metodus duomenų trūkiams užpildyti (Husler ir kt., 2014). Tam dažniausiai naudojami erdviniai ir laiko filtrų metodai (Voigt, 2000; Gafurov, Bardossy, 2009; Parajka ir kt., 2010). J. Parajka ir G. Bloschlas (2008) analizavo tris būdus, mažinančius debesų poveiki standartiniuose sniego dangos produktuose: 1) skirtingu palydovų teikiamos informacijos apjungimą; 2) erdvini filtravimą, kai apsiniaukusios paviršiaus gardelès reikšmès pakeičiamos gretimomis giedromis gardelemis; 3) filtravimą bėgant laikui, kai trūkiai užpildomi remiantis ankstesnių arba vèlesnių giedrų dienų informacija.

D. K. Hallo ir kt. (2010) tyrime teigiama, kad naudojant laiko filtrą sniego dangos žemèlapių trūkiams užpildyti geriausi rezultatai gauti esant mažam debesuotumui ar dažnai mainantis giedroms ir apsiniaukusiomis dienoms. F. Huslero ir kt. (2014) tyrime buvo taikomas debesų trūkių užpildymo metodas, pagrịstas erdvinès ir laiko kompozicijos kombinacija. Gautus duomenis palyginus su antžeminių meteorologijos stočių duomenimis, skirtumai buvo nedideli.

Lietuvoje sniego dangos rodikliai iki šiol nebuvo analizuojami remiantis palydovine informacija. Taigi nebuvo ir tiriama, kurie metodai naudojami duomenų trūkių užpildymui yra tinkamiausi mūsų šaliai. Šio tyrimo tikslas yra nustatyti palydovinès informacijos apie sniego dangą debesų sukeltų trūkių užpildymo metodų tinkamumą Lietuvos sąlygomis. Šiam tikslui buvo naudojami NASA (National Aeronautics and Space Administration) palydovu Terra ir Aqua bei Lietuvos meteorologijos stočių tinklui priklausančių stočių duomenys 2013-2016 metais. Darbe, naudojant skirtingus metodus, buvo užpildyti palydovinių sniego dangos duomenų sekų trūkiai, o gauti dydžiai palyginti su Lietuvos meteorologijos stotyse nustatytu dienų su sniego danga skaičiumi.

\section{PRADINIAI DUOMENYS IR DARBO METODIKA}

Tyrimui atlikti buvo naudojama Terra ir Aqua palydovų teikiama informacija bei Lietuvos meteorologijos stočių (MS) duomenys apie teritorijos padengtumą sniegu 2013-2016 metais. Tyrimui naudoti šaltojo laikotarpio (spalio-balandžio mèn.) sniego dangos duomenys. Terra ir Aqua pateikiamų sniego dangos duomenu (MOD10C1 colection 5, MYD1C1 Colection 5) tinklelio gardelès kraštinès dydis yra $0,05^{\circ}(\mathrm{MO}-$ DIS, 2018). Terra ir Aqua palydovai skrieja orbita, artima poliarinei, triju valandu skirtumu vienas nuo kito (National..., 2018). Terra ir Aqua palydovuose yra ịrengtas vidutinès raiškos spektroradiometras MODIS (Moderate-Resolution Imaging Spectroradiometer), kuris matuoja Saulès spinduliuotès atspindi (vieneto dalimis) nuo paklotinio paviršiaus 36 spektriniuose kanaluose (MODIS, 2018).

Sniegas labai stipriai atspindi Saulès spinduliuotę regimajame spektre, o artimojo infraraudonojo spektro diapazone atspindejimo geba labai susilpneja. Tai leidžia identifikuoti sniego dangą pagal regimųjų ir artimųjų infraraudonųjų bangų atspindžio stiprumo santykị. MODIS prietaisas, skriejantis Terra ir Aqua palydovuose, yra tinkamas distanciniams sniego dangos stebe்jimams, nes jis matuoja atspindžio stiprumą matomujjų ir artimųjų infraraudonųjų bangų spektruose (Riggs, Hall, 2004).

Sniego dangos duomenys palydoviniuose MODIS prietaisuose nustatomi remiantis normalizuotu sniego indeksu NDSI (Normalized Difference Snow Index). NDSI indeksas dažniausiai skaičiuojamas pagal formulę:

$\mathrm{NDSI}=\left(\mathrm{VIS}_{0,5}-\mathrm{NIR}_{1,6}\right) /\left(\mathrm{VIS}_{0,5}+\mathrm{NIR}_{1,6}\right)$

VIS - regimoji spinduliuote, o NIR - artimojo infraraudonojo spektro spinduliuotè. Skaičiai prie bangų tipo nurodo spektrinio kanalo viduriniu bangų ilgị $(\mu \mathrm{m})$.

Gardelè laikoma padengta sniegu, jei NDSI (Normalized Difference Snow Index) ir NDVI 
(Normalized Difference Vegetation Index) reikšmès patenka ì sniegui priskiriamą intervalą (Riggs, Hall, 2004). Sniego danga identifikuojama tuo atveju, kai NDSI (1 formulè) reikšmè yra didesnè nei 0,4. Papildomi kriterijai sniego dangos identifikavimui yra: 1) artimojo infraraudonojo spektro bangu $(0,86 \mu \mathrm{m})$ atspindejjimas didesnis nei 0,11 ; 2) $0,56 \mu \mathrm{m}$ bangos ilgio atspindejimas didesnis nei 0,10 (Riggs ir kt., 2006). Dèl šių papildomų kriterijų atsiranda didesnis patikimumas, kad fiksuojama sniego danga, o ne kitas paviršius.

Miškingose teritorijose daugelio sniegu padengtų gardelių NDSI yra mažesnis nei 0,4 , o kartais siekia vos 0,1 . Tada sąlyga sniegui nustatyti yra tokia: jei NDSI indekso reikšmè miško gardelèse yra tarp 0,1 ir 0,4 , sniegui teisingai identifikuoti papildomai skaičiuojamas NDVI indeksas (2 formulè), kurio reikšmé turètų būti mažesnè, palyginti su besniegèmis sąlygomis toje pačioje gardeleje (Klein ir kt., 1998; Riggs ir kt., 2006):

$$
\mathrm{NDVI}=\left(\mathrm{NIR}_{1,2}-\mathrm{VIS}_{0,6}\right) /\left(\mathrm{NIR}_{1,2}+\mathrm{VIS}_{0,6}\right) .
$$

Sniego dangos nustatymo algoritmai Aqua ir Terra palydoviniams duomenimis nèra identiški. Dèl Aqua palydove esančio MODIS 1,64 $\mu \mathrm{m}$ bangos detektoriaus $70 \%$ neveiksnumo, ịvykusio po palydovo paleidimo, naudojamos $2,13 \mu \mathrm{m}$ bangos atspindžio reikšmès. Tuo tarpu Terra pa- lydoviniams duomenims taikomame algoritme naudojamos artimojo infraraudonojo spektro $1,64 \mu \mathrm{m}$ bangos atspindžio reikšmès (Riggs ir kt., 2006).

Palydovinių duomenų verifikacijai buvo naudojami 18 Lietuvos meteorologijos stočių (1 pav.) duomenys. Stotyse stebėtojai supančios teritorijos padengtumą sniegu vertina dešimties balų sistema. Diena su sniego danga laikoma, kai meteorologijos stotyje fiksuotas padengimo sniegu balas didesnis už 5 (t. y. sniegu dengiama daugiau nei $50 \%$ aplinkinès teritorijos).

Palydoviniai sniego dangos duomenys buvo nuskaityti 18-oje gardelių, kuriose yra pasirinktos Lietuvos meteorologijos stotys. Gardelès pateikiamos $0,05^{\circ}$ tinklelyje, jos pasirinktos pagal tiriamų taškų koordinates. MODIS sniego dangos produkte reikšmės pateikiamos procentais ir parodo, kokia dalis gardelès yra padengta sniegu ir kokia debesimis. Jei debesys sudaro $95 \%$ ir daugiau gardelès, buvo laikoma, kad ji yra visiškai padengta debesimis. Jei sniego dengiama dalis sudarè mažiau nei $4 \%$, o debesys - mažiau nei $95 \%$, buvo laikoma, kad gardelè yra be sniego. Likusiais atvejais buvo skaičiuojamas normalizuotas dydis $N(\%)$ :

$$
N=\frac{S}{100-C} * 100
$$

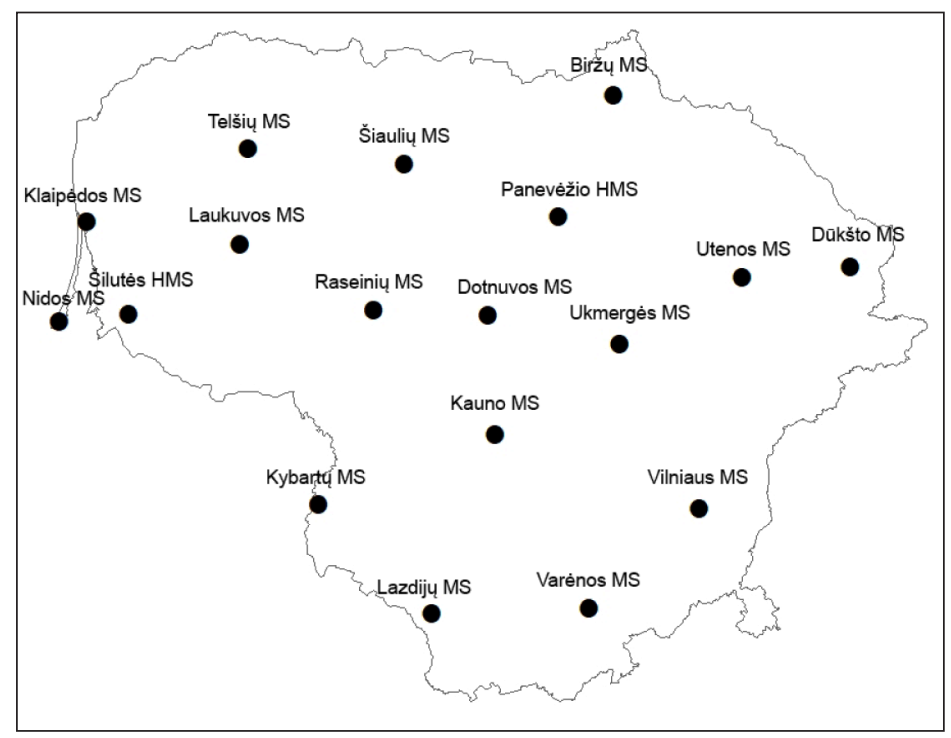

1 pav. Lietuvos meteorologijos stotys, kurių duomenys tyrime naudoti palydovinei informacijai tikrinti

Fig. 1. Location of meteorological stations in Lithuania, the data of which were used for satellite data verification in this study 
$S$ - sniego dengiama gardelès dalis, \%; $C$ - debesų dengiama gardelès dalis, \%. Jei $N$ reikšmè viršijo $50 \%$, buvo laikoma, kad gardelè padengta sniegu. Remiantis šia metodika, sudaryta dvejetainè seka, kurioje 0 reiškè paviršiu be sniego, o 1 - visiškai padengta sniegu. Ši metodika parengta remiantis N. Foppa ir G. Seizo tyrimu (Foppa ir Seiz, 2012).

Tiriamu 2013-2016 m. spalio-balandžio mèn. laikotarpiu MODIS duomenys atskleidè, kad virš pasirinktų meteorologijos stočių daugiau nei pusę dienų (vidutiniškai $60 \%$ ) fiksuoti trūkiai, atsiradę dèl debesuotumo (1 lentelè). Dviejuose trečdaliuose Lietuvos meteorologijos stočių tokių dienų buvo daugiau nei $60 \%$. Daugiausia trūkių buvo Rytų ir Pietų Lietuvoje - Vilniaus MS, Lazdijų MS, Utenos MS, Varènos MS, o mažiausia - pajūryje (Nidos MS ir Klaipèdos MS).
Daugiausia palydovo Terra informacijos trūkių dèl didelio debesuotumo fiksuojama lapkritị ir vasarị. Lapkritị 15-oje iš 18-os meteorologijos stočiu duomenų trūkiai vidutiniškai apėmè ilgesnị nei 20 dienų laikotarpi. Daugiausia palydovo Aqua duomenų trūkių fiksuota lapkritị ir sausị. Šiais mènesiais visose meteorologijos stotyse trūkiai vidutiniškai apèmé ilgesni nei 20 dienų laikotarpị.

Matavimų trūkiai dèl debesų dangos buvo užpildyti taikant vieną iš dviejų metodų. Pirmuoju atveju apsiniaukusi gardelè pakeičiama pagal tos pačios gardelès reikšmę paskutinę neapsiniaukusią dieną (trūkių užpildymas pirmyn). Antruoju atveju remiamasi pirmos po duomenų trūkio dienos reikšme (trūkių užpildymas atgal) (2 pav.). Naudojant abu metodus susidaro paklaidos (nustatomas per didelis arba per mažas dienų su sniego danga skaičius), tačiau laikoma, kad šie metodai sukuria

1 lentelè. Aqua ir Terra palydovų duomenų trūkių skaičius (\%) spalio-balandžio mèn. 18-oje Lietuvos meteorologijos stočių, 2013-2016 m.

Table 1. Number of Aqua and Terra satellite information data gaps (\%) at 18 meteorological stations in Lithuania in October-April 2013-2016

\begin{tabular}{c|c|c|c|c|c|c|c|c|c}
\hline & Biržai & Dotnuva & Dūkštas & Kaunas & Kybartai & Klaipėda & Laukuva & Lazdijai & Nida \\
\hline Aqua & 63 & 62 & 62 & 62 & 58 & 56 & 59 & 63 & 54 \\
\hline Terra & 61 & 59 & 64 & 62 & 58 & 55 & 60 & 64 & 56 \\
\hline & Panevėžys & Raseiniai & Šiauliai & Šilutė & Telšiai & Ukmergè & Utena & Varèna & Vilnius \\
\hline Aqua & 62 & 61 & 58 & 58 & 59 & 61 & 65 & 64 & 64 \\
\hline Terra & 60 & 62 & 60 & 56 & 58 & 63 & 62 & 62 & 64 \\
\hline
\end{tabular}

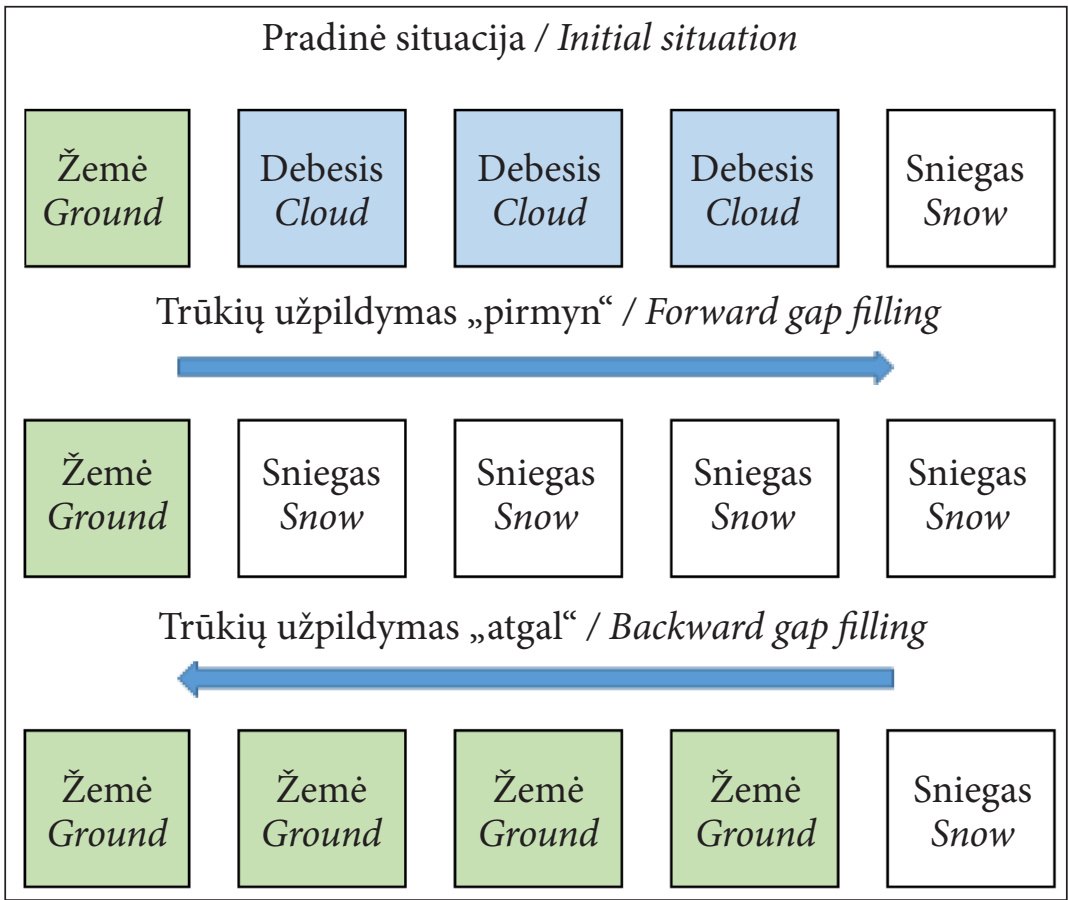

2 pav. Informacijos trūkių dèl debesuotumo užpildymo schema (Eumetrain ..., 2018)

Fig. 2. Scheme of temporal cloud gap data filling methodology (Eumetrain ..., 2018) 
priešingos krypties paklaidas, o naudojant jų vidurkị galima pakankamai tiksliai ịvertinti dienų su sniego danga skaičių per šaltąji sezoną (Foppa, Seiz, 2012).

Atliekant tyrimą duomenų sekos užpildytos naudojant pirmyn ir atgal metodus bei apskaičiuojant abiem metodais gautų dydžių vidurkį. Šie dydžiai palyginti su meteorologijos stotyse nustatytu dienų su sniego danga skaičiumi.

\section{REZULTATAI}

Vidutinis meteorologijos stotyse išmatuotas dienų su sniego danga skaičius per 2013-2016 m. žiemos sezoną Lietuvos teritorijoje buvo 47 dienos (3 pav.). Tai $47 \%$ mažiau nei vidutiniškai (pagal klimatinę normą). Iš 1981-2010 m. klimatinių normos duomenu matyti, kad vidutinis dienų su sniego danga skaičius Lietuvoje buvo 88 dienos. Šiltos žiemos pasižymi dideliu sniego dangos nepastovumu ir tai yra viena svarbiausių priežasčių, lemiančių santykinai didelius skirtumus tarp MS išmatuotų ir iš palydovinès informacijos apskaičiuotų dydžių. Be to, šiltos žiemos pasižymi cikloninès cirkuliacijos intensyvumu ir apsiniaukusių dienų skaičiumi, dèl ko didejja trūkių skaičius palydovinès informacijos sekose.

Vidutinis dienų su sniego danga skaičius pagal Terra palydovo duomenis minètomis žiemomis buvo 44 dienos, o pagal Aqua - 55 dienos. $80 \%$ atvejų, remiantis atskirų MS duomenimis, daugiau sniego dienų fiksavo Aqua palydovas. Kiek didesnès reikšmès fiksuotos trūkius užpildžius pirmyn metodu, tačiau skirtumas yra nedidelis, jis neviršija vienos dienos. Taigi galima teigti, kad trūkių užpildymo metodo pasirinkimas turi mažai įtakos sezoninio dienų su sniego danga skaičiui, nustatytam naudojant palydovų duomenis.

Analizuojant dienų su sniego danga skaičiaus pasiskirstymą per sezoną nustatyta, kad pirmoje sezono pusėje dienų skaičius meteorologijos stotyse yra artimas vidutiniam dydžiui, nustatytam iš Terra palydovo duomenų (4 pav.). Spalio-sausio mèn. šis skirtumas neviršija vienos dienos. Tuo tarpu vasario ir kovo mèn. skirtumas nežymiai išauga - meteorologijos stotyje fiksuojamos didesnès rodiklio reikšmès. Didesni skirtumai

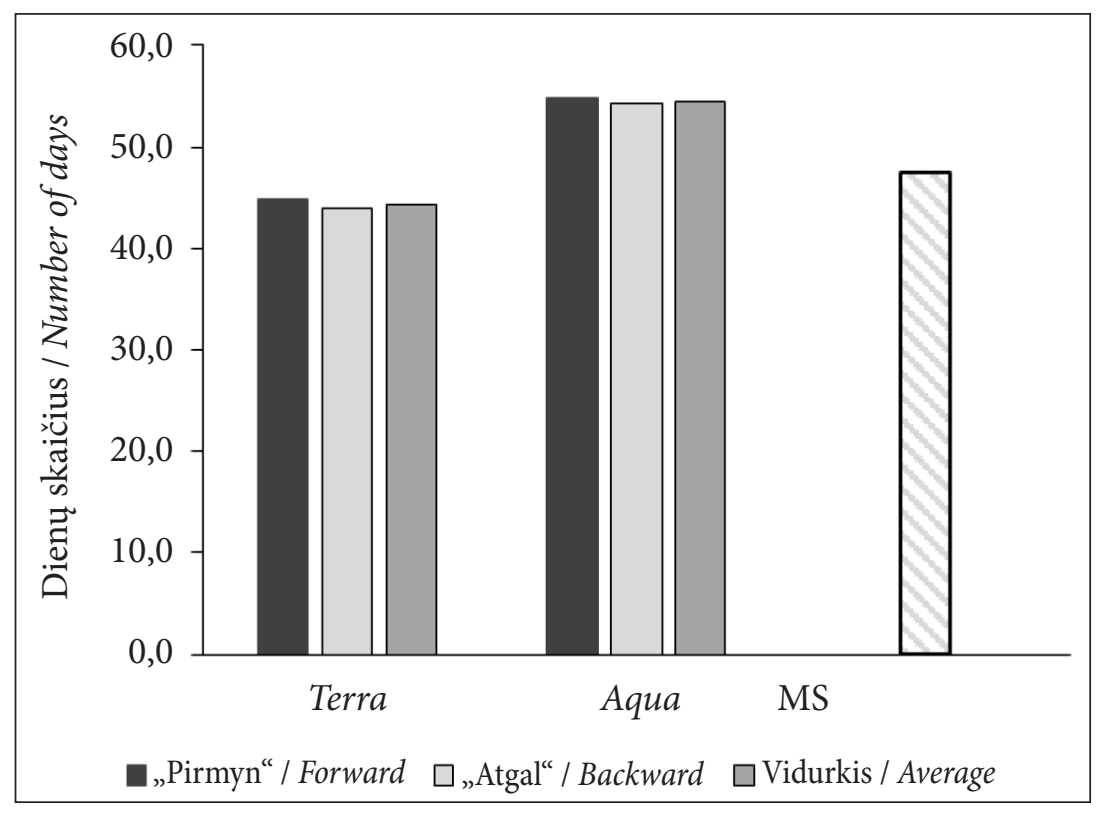

3 pav. Vidutinis dienų su sniego danga skaičius Lietuvos teritorijoje 2013-2016 m. šaltaisiais sezonais, remiantis skirtingais metodais užpildytomis Terra ir Aqua palydovų duomenų sekomis ir išmatuotas Lietuvos meteorologijos stotyse (MS)

Fig. 3. The average number of snow cover days in Lithuania during 20132016 cold seasons, based on Terra and Aqua satellite data with cloud gaps filled using different methods, and the average number of snow cover days observed at Lithuanian meteorological stations (MS) 


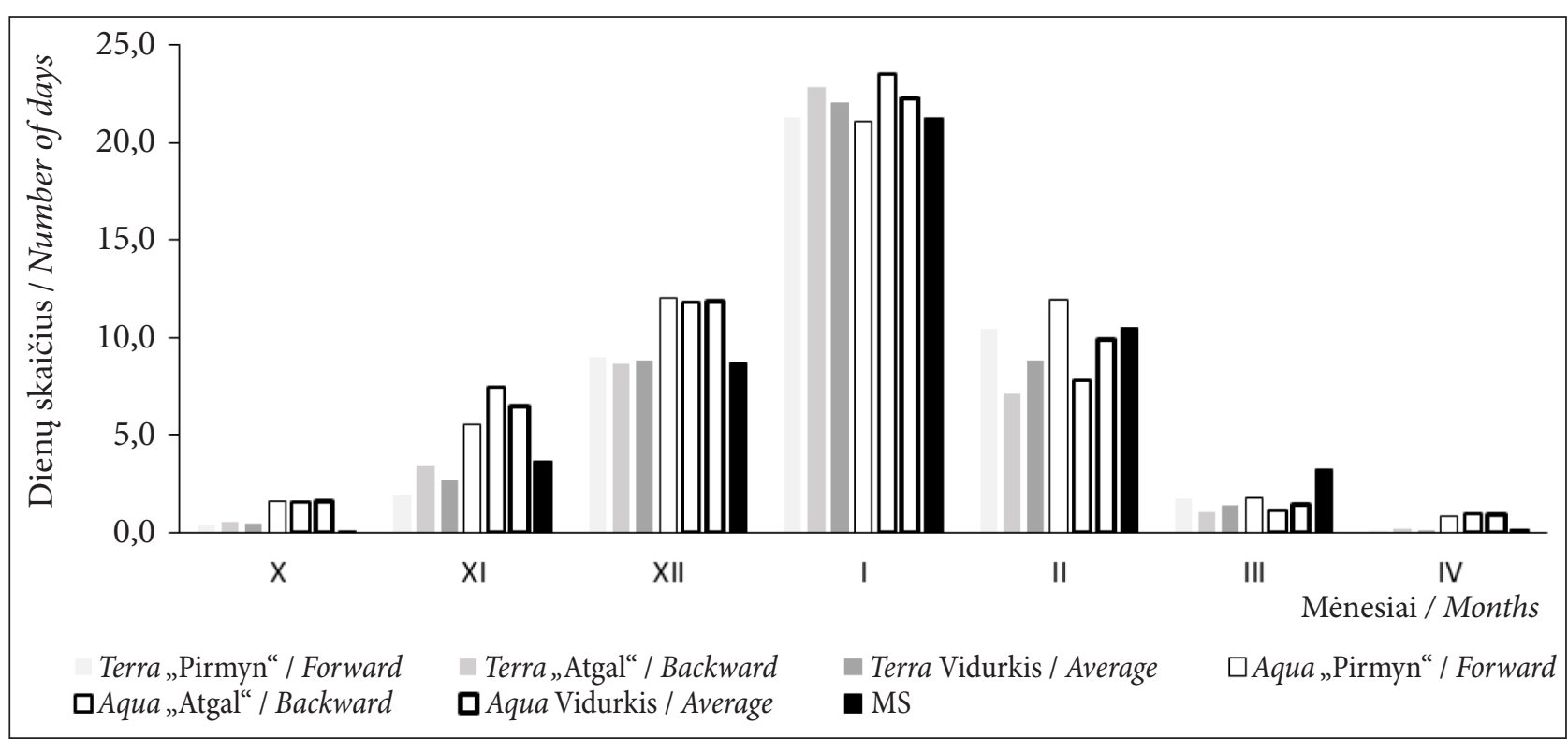

4 pav. Vidutinis dienų su sniego danga skaičius atskirais 2013-2016 m. šaltojo sezono mènesiais Lietuvos teritorijoje, remiantis skirtingais metodais užpildytomis Terra ir Aqua palydovų duomenų sekomis ir išmatuotas Lietuvos meteorologijos stotyse (MS)

Fig. 4. The average number of snow cover days during cold seasons in Lithuania in 2013-2016 based on Terra and Aqua satellite data with cloud gaps filled using different methods, and mean number of snow cover days observed at Lithuanian meteorological stations (MS)

gali būti sietini su sniego dangos fragmentacija tirpimo metu. Dienų su sniego danga skaičius, nustatytas Aqua palydovo, yra didesnis nei stebètas MS. Šie skirtumai tarp palydovų gali būti nulemti besiskiriančio algoritmo, skirto sniego dangos identifikavimui.

Pirmoje sezono pusèje didesnès reikšmès fiksuojamos naudojant trūkių užpildymo metodą atgal, o vasario ir kovo mèn. - pirmyn. Tai aiškintina tuo, kad sniego akumuliacijos laikotarpiu egzistuoja didesnè tikimybé, kad paskutinè apsiniaukusio laikotarpio diena bus su sniego danga, o pirma - be sniego, nei priešingai, t. y. apsiniaukęs periodas prasidès diena su sniego danga, o baigsis besniege diena. Šiuo atveju naudojant metodą atgal visas duomenų trūkio laikotarpis bus traktuojamas kaip laikotarpis su sniego danga. Tuo tarpu pavasario mèn. priešingai: didesnè tikimybè, kad trūkio pradžioje bus diena su sniego danga, o trūkis baigsis diena be sniego. Šiuo atveju santykinai išauga apskaičiuotas dienų skaičius naudojant trūkių užpildymo metodą pirmyn.

Tiriamu 2013-2016 m. laikotarpiu spalio ir balandžio mèn. dienų su sniego danga meteorologijos stotyse beveik nebuvo, tačiau kelias dienas palydovai neteisingai identifikavo, palaikè sniegingomis. Tai rodo, kad reikalingi papildomi duomenų kontrolès metodai (pvz., temperatūros kontrolè, kai sniego danga negali būti identifikuojama, jei oro temperatūra viršija tam tikrą nustatytą ribą).

Atskirose meteorologijos stotyse skirtumai yra daug didesni nei vidutiniai dydžiai visoje Lietuvos teritorijoje (2 lentelè). Vidutiniškai sezoninis dienų su sniego danga skaičius nustatytas palydovų nuo išmatuoto atskirose meteorologijos stotyse skiriasi devyniomis dienomis pagal Terra palydovo duomenis ir 13 dienų pagal Aqua palydovą. Pagal Terra palydovą, $33 \%$ atvejų šis skirtumas neviršija trijų dienų ir taip pat $33 \%$ atvejų viršija 10 dienų (pagal Aqua palydovą atitinkamai $17 \%$ ir 52 \%). Tik Kybartų MS 2013-2014 m. žiemą išmatuotas dienų su sniego danga skaičius visiškai sutapo su Terra palydovo duomenis. Tuo tarpu didžiausias skirtumas (48 dienos) buvo užfiksuotas 2015-2016 m. lyginant Varènos MS ir Aqua palydovo duomenis.

10 meteorologijos stočiu Terra palydovo duomenys yra vidutiniškai artimesni išmatuotiems, o aštuonių - Aqua. Jei naudotume abiejų palydovų teikiamos informacijos vidurki, tai toks vidutinis skaičius arčiausiai išmatuoto MS būtų trijose MS 
2 lentelè. Dienų su sniego danga skaičius išmatuotas atskirais šaltaisiais sezonais Lietuvos meteorologijos stotyse (MS) bei nustatytas iš Terra ir Aqua palydovų duomenų (dviejų trūkių užpildymo metodų vidurkis)

Table 2. The number of snow cover days at Lithuanian meteorological stations (MS) during different cold seasons and the number of snow cover days based on Terra and Aqua satellite information (the average of two gap filling methods)

\begin{tabular}{|c|c|c|c|c|c|c|c|c|c|c|c|c|}
\hline \multirow{2}{*}{$\begin{array}{l}\text { Meteorologijos } \\
\text { stotis } \\
\text { Meteorological } \\
\text { station }\end{array}$} & \multicolumn{3}{|c|}{ 2013-2014 } & \multicolumn{3}{|c|}{ 2014-2015 } & \multicolumn{3}{|c|}{ 2015-2016 } & \multicolumn{3}{|c|}{$\begin{array}{l}\text { Vidurkis } \\
\text { Average }\end{array}$} \\
\hline & Terra & Aqua & MS & Terra & Aqua & MS & Terra & Aqua & MS & Terra & Aqua & MS \\
\hline Biržai & 21 & 33 & 37 & 52 & 78 & 73 & 46 & 49 & 52 & 40 & 53 & 54 \\
\hline Dotnuva & 47 & 47 & 36 & 42 & 47 & 56 & 37 & 51 & 49 & 42 & 48 & 47 \\
\hline Dūkštas & 26 & 32 & 50 & 64 & 83 & 85 & 46 & 71 & 83 & 45 & 62 & 73 \\
\hline Kaunas & 42 & 46 & 38 & 40 & 35 & 57 & 44 & 41 & 43 & 42 & 41 & 46 \\
\hline Klaipèda & 33 & 53 & 31 & 25 & 14 & 21 & 22 & 32 & 24 & 27 & 33 & 25 \\
\hline Kybartai & 32 & 63 & 32 & 31 & 24 & 28 & 25 & 39 & 28 & 29 & 42 & 29 \\
\hline Laukuva & 40 & 74 & 39 & 76 & 80 & 64 & 71 & 97 & 67 & 62 & 84 & 57 \\
\hline Lazdijai & 40 & 39 & 44 & 62 & 83 & 69 & 34 & 43 & 39 & 45 & 55 & 51 \\
\hline Nida & 37 & 38 & 36 & 23 & 36 & 26 & 28 & 30 & 22 & 29 & 35 & 28 \\
\hline Panevëžys & 34 & 32 & 38 & 40 & 38 & 64 & 44 & 52 & 49 & 39 & 41 & 50 \\
\hline Raseiniai & 53 & 67 & 40 & 58 & 69 & 57 & 59 & 62 & 59 & 56 & 66 & 52 \\
\hline Šiauliai & 48 & 54 & 41 & 51 & 52 & 53 & 39 & 50 & 56 & 46 & 52 & 50 \\
\hline Šilutė & 37 & 43 & 35 & 38 & 54 & 30 & 22 & 47 & 24 & 32 & 48 & 30 \\
\hline Telšiai & 36 & 57 & 37 & 60 & 72 & 62 & 62 & 72 & 73 & 53 & 67 & 57 \\
\hline Ukmergè & 40 & 60 & 37 & 63 & 84 & 60 & 48 & 62 & 42 & 50 & 68 & 46 \\
\hline Utena & 40 & 31 & 37 & 73 & 71 & 66 & 64 & 55 & 49 & 59 & 52 & 51 \\
\hline Varèna & 64 & 83 & 43 & 73 & 96 & 61 & 45 & 95 & 47 & 60 & 91 & 50 \\
\hline Vilnius & 52 & 48 & 47 & 38 & 54 & 76 & 44 & 38 & 51 & 44 & 47 & 58 \\
\hline
\end{tabular}

(tais atvejais, kai Terra ir Aqua nuokrypiai yra priešingo ženklo). Analizuojant tiriamus sezonus po vieną, $67 \%$ artimesni rezultatai gauti naudojant Terra palydovo duomenis. Galima teigti, kad dviejų palydovų informacijos kombinavimas neturi didelès teigiamos įtakos galutinių duomenų kokybei (Terra palydovo informacija mažiausiai skiriasi nuo MS).

Tai, kad Varèną dengiančioje gardelejje palydovai fiksuoja daug daugiau dienų su sniego danga nei MS (5 pav.) (vidutiniškai $20 \%$ pagal Terra palydovą ir net $81 \%$ daugiau pagal Aqua) galima aiškinti itin miškinga teritorija, o sniegas miškuose išsilaiko ilgiau pavasarị bei gali išlikti ir per ilgesnius atodrèkius. Tuo tarpu Varénos meteorologijos stoties (įrengtos atokiau nuo miško) apylinkèse sniego danga yra labiau kintanti. Skirtumo tarp palydovinių ir antžeminių matavimų negalima laikyti palydovinių matavimų trūkumu, kadangi jų informacija geriau nei meteorologijos stotis reprezentuoja vidutines vietovès sąlygas. Be to, sniegui identifikuoti miškingose teritorijose papildomai skaičiuojama ir NDVI reikšmè (2 formulè). Stotys, kuriose nustatytas dienų su sniego danga skaičius yra mažesnis nei apskaičiuotas iš palydovu teikiamos informacijos, daugiausia yra vakarineje Lietuvos dalyje, kur sniego danga šiltomis žiemomis yra itin nepastovi (5 pav.).

Dalyje stočių dienų su sniego danga skaičius fiksuojamas didesnis nei apskaičiuotas remiantis palydovine informacija. Daugiausia jų šiaurinèje bei rytinejje Lietuvos dalyje, kur sniego danga pasižymi didesniu pastovumu ir išsilaiko ilgiau. Išsiskiria Dūkšto MS, kur dienų su sniego danga yra nustatyta vidutiniškai $38 \%$ daugiau, nei naudojant Terra palydovo duomenis ir $15 \%$ daugiau nei Aqua palydovo duomenis. Šioje vietoveje matavimų tikslumą gali paveikti ir gana didelis gardelès ežeringumas, kadangi atspindys nuo vandens ar švaraus (be sniego) ledo paviršiaus stipriai skiriasi nuo sniego atspindžio sausumoje. 


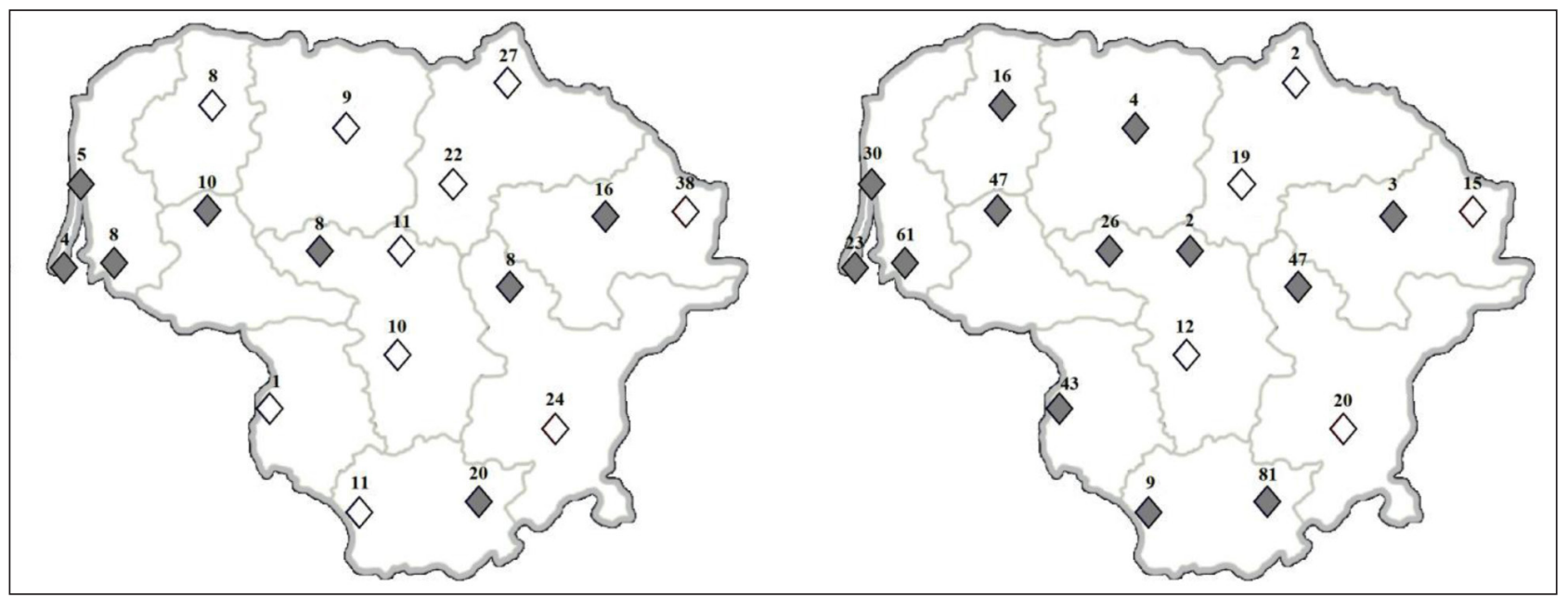

5 pav. Terra (kaireje) ir Aqua (dešinėje) palydovų ir Lietuvos MS nustatytų dienų su sniego danga skaičiaus vidutinis skirtumas (\%). 2013-2016 m. spalio-balandžio laikotarpio duomenys (pilkas rombas žymi, kad daugiau dienų su sniego danga fiksuota palydovo, baltas - meteorologijos stotyje)

Fig. 5. The difference (\%) of the number of snow cover days estimated using Terra (left) and Aqua (right) satellite data and observed at meteorological stations from October to April in 2013-2016 period (gray mark indicates stations where more snow cover days were determined by satellite, while white - at meteorological stations)

Būtina paminèti, kad visos trys nagrinejjamos žiemos buvo mažai sniegingos, o sniego danga nuolatos kito. Dažni atodrèkiai ir sniego dangos fragmentacija (nemažai dienų, kai meteorologijos stoties apylinkèse sniego danga nebuvo ištisinè) kartu su didele duomenų trūkių dalimi lèmè ir nemažus skirtumus tarp dienų su sniego danga skaičiaus, išmatuoto MS bei nustatyto naudojant palydovinę informaciją. Galima daryti prielaidą, kad šaltomis ir sniegingomis žiemomis (tiriamu laikotarpiu tokių žiemų nebuvo) dviejų informacijos šaltinių pateikiamas dienų su sniego danga skaičius skirtųsi mažiau (ypač procentinè jo išraiška), nepriklausomai nuo to, kiek yra trūkių palydovinés informacijos sekoje. Ateityje, siekiant pagerinti iš palydovų gautos informacijos tikslumą, būtina papildomai naudoti informaciją iš gretimų, debesų nedengiamų gardelių ir parinkti tinkamas kritines reikšmes temperatūros kontrolei.

\section{IŠVADOS}

1. Didžiojoje Lietuvos dalyje Terra palydovo duomenys geriau nei Aqua palydovo duomenys atitinka dienų su sniego danga skaičių išmatuotą meteorologijos stotyse. Nustatyta, kad dviejų palydovų informacijos apjungimas iš esmès nepagerina gaunamos informacijos kokybès. Trijų sezonų dienų vidurkis pagal Terra palydovą nuo išmatuoto me- teorologijos stotyse skiriasi trimis dienomis. Šis skirtumas mažesnis sniego akumuliacijos periodu, o sniegui tirpstant jis išauga.

2. Nors didesnès reikšmès gautos palydovinès informacijos trūkius užpildžius metodu pirmyn, tačiau skirtumai yra nedideli ir abiejų palydovu atveju vidutiniškai neviršija vienos dienos. Todèl galima teigti, kad Lietuvos sąlygomis nèra itin svarbu, kuris iš dviejų analizuotų trūkių užpildymo metodų yra pasirenkamas.

3. Atskirose meteorologijos stotyse nustatyti skirtumai tarp išmatuoto ir remiantis palydovine informacija apskaičiuoto dienų su sniego danga skaičiaus yra didesni nei teritorijos vidurkis. Vidutiniškai sezoninis dienų skaičius nuo išmatuoto meteorologijos stotyje skiriasi devyniomis dienomis pagal Terra palydovo duomenis ir 13 dienu pagal Aqua palydovą. Vakarų Lietuvoje daugiau dienų su sniego danga dažniausiai gaunama remiantis palydovų, o Rytų - meteorologijos stočių duomenimis. Šių skirtumų dydis gali būti nulemtas ir meteorologijos stoties apylinkių landšafto ypatumų (miškingumo, ežeringumo ir kt.). Siekiant didesnio palydovinès informacijos tikslumo reiktų papildomai panaudoti gretimų giedrų gardelių duomenis ir vykdyti temperatūros kontrolę.

Gauta 20181119

Priimta 20181128 


\section{LITERATŪRA}

1. Beniston M. 1997. Variations of snow depth and duration in the Swiss Alps over the last 50 years. Links to changes in large-scale climatic forcings. Climatic Change. 36: 281-300.

2. Eumetrain training module. Climatology of Snow Cover and Snow Water Equivalent. http://www. eumetrain.org/resources/snow_climatology.html (žiūreta 201811 15).

3. Foppa N., Seiz G. 2012. Inter-annual variations of snow days over Switzerland from 2000-2010 derived from MODIS sattelite data. The Cryosphere. 6: 331-342.

4. Gafurov A., Bardossy A. 2009. Cloud removal methodology from MODIS snow cover product. Hydrology and Earth System Science. 13: 1361-1373.

5. Hall D. K., Riggs G. A., Foster J. L., Kumar S. V. 2010. Development and evaluation of a cloud-gapfilled MODIS daily snow-cover product. Remote Sensing of Enviroment. 114: 496-503.

6. Hantel M., Hirtl-Wielke L. M. 2007. Sensitivity of Alpine snow cover to European temperature. International Journal of Climatology. 27: 1265-1275.

7. Husler F., Jonas T., Riffler M., Musial J. P., Wunderle S. 2014. A satellite-based snow cover climatology (1985-2011) for the Europian Alps derived from AVHRR data. The Cryosphere. 8: 73-90.

8. Klein A. G., Hall D. K., Riggs G. A. 1998. Improving snow cover mapping in forest through the use of canopy reflectance model. Hydrological Processes. 12: $1723-1744$.

9. Laternser M., Schneebeli M. 2003. Long-term snow climate trends of the Swiss Alps (1931-99). International Journal of Climatology. 23(7): 733750.

10. Marty C. 2008. Regime shift of snow days in Switzerland. Geophysical Research Letters. 35: L12501.
11. Marty C., Meister R. 2012. Long-term snow and weather observations at Weissfluhjoch and its relation to other high-altitude observatories in the Alps. Theoretical and Applied Climatology. 110: 573-583.

12. MODIS. https://modis.gsfc.nasa.gov/data/dataprod/ mod10.php (žiūrèta 201811 15).

13. National Snow and Ice Data Center. Terra vs. Aqua. https://nsidc.org/data/modis/terra_aqua_differences (žiūrèta 201811 15).

14. Parajka J., Bloschl G. 2008. Spatio-temporal combinations of MODIS images - Potential for snow cover mapping. Water Resources Research. 44: 23652377.

15. Parajka J., Pepe M., Rampini A., Rossi S., Bloschl G. 2010. A regional snow-line method for estimating snow cover from MODIS during cloud cover. Journal of Hydrology. 381: 203-212.

16. Riggs G. A., Hall D. K. 2004. Snow Mapping with the MODIS Aqua Instrument. Proceedings of 61st Annual Eastern Snow Conference. Portland, Maine, USA. 81-84.

17. Riggs G. A., Hall D. K., Salomonson V. V. 2006. MODIS Snow product user guide to Collection 5 . https://modis-snow-ice.gsfc.nasa.gov/uploads/sug_c5 (žiūrèta 201811 15).

18. Scherrer S. C., Appenzeller C. 2006. Swiss Alpine snow pack variability: major patterns and links to local climate and large-scale flow. Climate Research. 32(3): 187-199.

19. Scherrer S. C., Appenzeller C., Laternser M. C. 2004. Trends in Swiss Alpine snow days - the role of local- and largescale climate variability. Geophysical Research Letters. 31: L13215.

20. Voigt S. 2000. Advanced Methods for Operational Mapping of Alpine Snow Cover Using Medium Resolution Optical Satellite Data. Inauguraldissertation, University of Bern, Switzerland. 
Silvija Pipiraitė-Januškienė, Justinas Kilpys, Egidijus Rimkus

\section{EVALUATION OF SATELLITE-BASED SNOW COVER PRODUCT DATA GAPS FILLING METHODS}

Summary

Over the last decades, satellite information is increasingly used to measure different snow cover characteristics. However, the information provided by the satellite-based instruments working in the visible and near infra-red spectrum have large data gaps due to the cloud cover.

The aim of this study is to evaluate different temporal cloud gap filling methods in MODIS (ModerateResolution Imaging Spectroradiometer) snow cover products over Lithuania. For this purpose, MODIS data from NASA Terra and Aqua satellites from 20132016 were used. Verification of satellite-derived snow cover days was done using ground measurements from 18 meteorological stations in Lithuania.

During the cold periods (October to April) of 20132016 , on average, $60 \%$ of the days were cloud-covered at the location of meteorological stations. Data gaps in Terra and Aqua MODIS snow products were filled using two temporal filling methods. In the first method, the cloudy grid cell value is replaced by the value in the same grid cell from the last clear sky day (the forward method). In the second method, the cloudy grid cell value is replaced by the value of the first clear sky day after the overcast period (the backward method).
The average number of days with snow cover observed at meteorological stations in Lithuania during the winter seasons in 2013-2016 was 47 days. The average number of days with a snow cover derived from Terra satellite information was 44 days and from Aqua satellite -55 . By filling the gaps with the forward method, the number of snow cover days was slightly higher, but the difference was small and it did not exceed one day for both satellites.

In the first part of the cold season, the number of snow cover days derived from Terra satellite data had a high agreement with the number of snow cover days determined at meteorological stations. Meanwhile, in February and March, the difference was higher and satellite data tended to underestimate the number of snow cover days. Larger differences between ground and satellite observations can be related to the fragmentation of the snow cover during the melting period.

On average, the seasonal numbers of snow cover days determined by Terra and Aqua satellites differed from those measured at meteorological stations by 9 and 13 days, respectively. The study showed that combination of information from these two satellites does not significantly improve the estimation of snow cover days.

In order to improve the estimation of snow cover days from satellite information, it is necessary to use additional filtering. Future studies could include spatial filtering using information from neighbouring grid cells and using temperature thresholds to filter false detection of snow.

Keywords: snow, number of snow cover days, Terra, Aqua, MODIS, cloud cover, data gaps 